\title{
In Lee Bom Son's Story "Stray Bullet”, the Issue of the Negative Consequences of the Civil War is Highlighted
}

\author{
Umida Saydazimova ${ }^{1}$, Durdona Murodova ${ }^{2}$ \\ ${ }^{1}$ DsC, Associate Professor,Tashkent State University of Oriental \\ Studies,Tashkent,Uzbekistan \\ ${ }^{2}$ Senior Lecturer, Tashkent State University of Oriental Studies, Tashkent, Uzbekistan
}

\begin{abstract}
This article highlights the negative consequences of the Civil War in Lee Bom Son's story "Stray bullet". The writer's ability is determined by how well he analyzes the human spiritual world, how he reveals and describes his multifaceted and complex activities, as well as how he tells people new things based on the events he writes about.
\end{abstract}

Keywords: "Stray bullet", human character, Civil War, artistic expression,family.

Article Received: 10 August 2020, Revised: 25 October 2020, Accepted: 18 November 2020

\section{Introduction}

The stories of the well-known Korean writer Lee Bom Son meet the above criteria. The writer began his career in the story genre. It is well known that a story covers a certain part of life and is based on a part of a person.If the fact on which the story is based does not have a great truth, the expression becomes not a story, but merely a sheet, a simple statement of a past event.Lee Bom Son pays special attention to these features of the genre in his stories.

In general, the writer uses such a decisive event in history as an important tool in his stories to show human character in connection with the conditions of the Korean Civil War, to give an artistic expression of life, human characteristics.His story "Stray bullet" is especially important in Korean Civil War prose. It is no coincidence that this story was nominated for a literary prize.

Lee Bom Son's story "Stray bullet"shocked the entire literary community.Not only is it a simple moving story, but the real test that the Korean people are going through after the Civil War, if it can be called nihilism, is a description that fits perfectly into the life of that period, "Stray bullet".It is also commendable that the lifestyles of the common people are included in the images as the most alternative. It is no exaggeration to say that this "Stray bullet" story is one of the greatest works created by Lee Bom Son, but it is a big wave of modern Korean storytelling.In the play, the original way of life of the Korean people, a people with a clear conscience and the lives of ungrateful invaders, means that humanity must fight for survival.Author Kim Hyun's description of this story as such is proof of our opinion above. "Lee Bom Son has created a work that is so mature that critics can't say too much.The life of an ordinary people who enjoys life with his family, even though he lives on a salary that never comes out of a life buried in nostalgia for his homeland ...The people who chase death out of poverty and do not sell their conscience and faith ... This is the culmination of "Stray bullet".

Peck Sing Chol writes about the work: "Stray bulletis a reflection of a people wandering around without finding their way in life, a great work that helps to find unanswered answers to endless questions by expressing the way of life of that time.The most important thing is that a person does 
not lose his identity in any case, that is the real courage".

"It should be noted that the writers who wrote about the war both at that time and after the end of the war reflected the spirit of this period more deeply. Such writers make up a whole series in the literature" [1. 108]. The same is true for Korean writer Lee Bos Son.

Indeed, one aspect of Lee Bom Son's prose work attracts attention. The issue of war and human destiny he addressed not only in the days of the Civil War, but also in the later work of the writer, this theme took a certain place as a problem of a divided nation.In particular, in his later works the division of Korea into two, the people's exposure to two different ideologies, the negative consequences of this on the fate of the people, the spiritual decline are observed.

\section{The Main Findings and Results}

In the story "Stray bullet", the writer managed to show that the inhuman nature of the Civil War, the incomparable tragedy and tragedy that befell the people, is an endless tragedy for the Korean people.The protagonists of the work, especially the mother, do not understand what kind of war is going on, against whom, and why they cannot go to the place where they were born and raised.

The protagonists of the story do not speak directly about it, on the contrary, this content stems from the essence of their actions and thoughts.In particular, this is evident in the mother's constant repetition of "Let's go back!"

Writer Lee Bom Son was also able to leave a deep imprint on the hearts of readers with his ability to shed light on the negative consequences of the Civil War through the life of a family.His works of this type tell people in detail how the brutality of war and the inappropriate interference of political forces can wreak havoc on the people.
In Lee Bom Son's artistic views and works, including the story of "Stray bullet" the people's helplessness, their inability to demand their rights, is combined with a spiritual awakening. The author opposes the tricks of politically powerful states from a social point of view, trying to convince the country to get rid of oppression.

The story depicts the suffering of a nation that could not give up its national way of life due to the Japanese annexation, then the civil war and the capitalist system, and adapt to a new life and change in the form of a small family and heroes.

In his work, the writer expresses the tragic truth in the language of ordinary people, and the heroes of the work also live with hope for the future. Lee Bom Son, who focuses on the fate of the family as a part of society, is an author describing the complications of war.The writer was also able to vividly and vividly portray the consequences of the Civil War as he tasted the hardships of Japanese rule. The realities of the existing world, the cautious approach to life, made Lee Bom Son a representative of "true literature" who was able to reflect his feelings of humanity.The works he created encourage the reader to observe deeply and have risen to the level of immortal works not only in keeping with the times in which he lived, but also with the social situations of today.

Lee Bom Son shook his pen based on his sharp observation on painful and wideranging issues such as the scope of the topics he raised in his works, the period of the Civil War, the division of the country and the nation.Indeed, this story, written by him, immerses the reader in an inseparable world of thought. The "ideological battles" embodied in the story are the main reason for this.It is an undeniable fact that the author has a strong position in the world of literature through the scope and methodology of these topics. It should also be noted that in the world of Korean literature, there are not many people like Lee Bom Son who raise the current problems of society, the issue of a divided nation, 
globalization, seeking a cure and finding painful solutions.The reason why the author's works come to life is that the writer saw and felt the problems in his works with his own eyes.

Lee Bom Son's prose also shifted in the 1960s as a new era of historical change began in Korea, signifying a complete reversal from medieval to modern times, a renewal of socio-political thinking, and an objective assessment of national and cultural values. The fact that these processes, including the development of Korean literature, also occurred due to political and social factors, did not limit the works of Lee Bom Son and his contemporary writers. In modern Korean literature, all of the works created after the achievement of state freedom and liberty were united by one common point, and this point did not limit the works of Lee Bom Son either.While living in his homeland, he shared the fate of many of his countrymen on the brink of poverty, ordinary people surrounded by daily worries, the most important problems such as finding food for daily living, being forced to leave the country in need of food, to earn money the decision to go to other countries, to leave the country to follow the missionaries, to build a new ideological country after his return, witnessed the plight of a group of emigrants who faced life's trials. At the same time, it should be noted that by this time the territorial and ideological struggle for freedom has become the focus, not on the basis of a single goal.

Lee Bom Son differs from contemporary writers in that he gives titles and mutual interpretations to his works.In particular, in the work "Stray bullet"Stray bullet means the fate of a wandering man, whose destination is unknown.

As a result of the writer's talent, his stories are works that have the character of making the modern reader feel how hard the Civil War was for the Korean people.

Lee Bom Son is also a creator of works with an ideological style and philosophical outlook, as he has experienced most of the themes in his pen.Of course, the sufferings of the people after independence and independence created the basis for the writer to write in such a style.Indeed, in these two periods, external influences on the transition of culture from one form to another, namely the socio-cultural situation, the opening of the outside world to Korea after centuries of oppression, the growing role of cities and, in particular, literary influence: the crisis of traditional literature, the discovery of new ways of artistic mastery of the world, the ideological twists in the world of literature caused by the interaction of tradition and innovation, completely different from the previous literature, traditions, new ideological and philosophical-aesthetic concepts became a generalized spiritual phenomenon.

Literature and the period have always been in step. As each writer chooses a protagonist for his or her work, he or she seeks to portray himself or herself as the protagonist, to portray his or her life through his or her protagonist, to reveal his or her attitude to life, and to idealize the protagonist. The protagonist of Lee Bom Son's story "Stray bullet"also reflects the social problems of the time.

A talented writer is always in tune with the times, intelligently understands the essence of change and expresses his attitude to it. This is how a work born is readable, impressive and attractive. Because such works the contradiction of the period is revealed.Lee Bom Son is a contemporary writer with such a period.

It is natural for a writer to express his attitude to the period in which he lived, to his problems and achievements, in the material of life in which he excited himself or held a pen in his hand. The theme of "Stray bullet"is the life of the Korean people in the middle of the XX century, ie in 19501953. When Lee Bom Son called his work "Stray bullet," he aimed to shape the problem of the period in the subject of the work. A work of art is born as a product of the artist's relationship with being. That is, as an individual living in existence, the creator thinks about certain problems, 
worries. The artist also touches on the work because his desire to understand that problem has become an inner need.So, the problem is primary in terms of its emergence and motivation, and in order for the artist to understand that problem artistically, the creator separates the material of life, which is the subject of the work of art. That is, the problems that concern the creator determine the theme of the work. The main theme of Lee Bom Son's work is "the darkest days in the history of the Korean people."

The main idea expressed by the writer in a work of art, his assessment of the subject of the image, is called the "idea of the work."[2]The main idea of "Stray bullet"is to show the consequences of the Japanese occupation in the history of the Korean people, the darkest days in the history of the nation, which were divided by two foreign powers - the United States in the south and the former Soviet Union in the north.

An artistic idea is a figurative idea[3]. It stems from an objectively depicted landscape, the destiny of people, the logic and essence of events. In the story "Stray bullet"we see a broad and realistic picture of the life of the Korean people at that time, which gained independence after the Japanese invasion.

The protagonist Chol-ho is in no hurry to go home after work every day. Because he is not interested in the end of working hours, hunger, not having lunch, he suffers from going back home. Even the cleaning lady's words about having to go home annoy him.Knowing that he had to leave, Chol-ho reluctantly repeated the word "I have to go" every time. These words always sound like the sorrow of death, that he could not get the result he wanted, that he could not give up his destiny.Every day, the cleaner starts sweeping from one end of the office without waiting for her to vacate the room. Only when the dust rose from the floor did Chol-ho slowly move.

The role of environmental and period politics and ideology in the formation of human nature and beliefs is great. The period of Japanese occupation is a clear example of this.It is well known that the "sponsorship" agreement reached at that time was devoid of democratic principles and served the Japanese government, which came to the throne in exchange for violence and false promises, instead of giving meaning to public life.An ideology of injustice and cruelty, completely devoid of democratic principles, was instilled in the minds of the people on the basis of deception and violence, and as a result, a civil war broke out among the beleagured people.

The place where the protagonist of the story lives is a mess of poor houses at the foot of the mountain. Every day after work, Chol-ho Jin enters one of the streets.The roofs of the houses are narrow and tasteless streets at the level of the head. The splashing water from the kitchens of the apartments, the remnants of food froze in the cold air, and the streets were slippery.At the end of this street is Sol-ho's house, a white-gray house with only a name on the window sill. The cloth, which resembles a leather strap, is used as a door handle. The door does not close tightly.

In the Civil War, someone lost their father, someone their mother, someone their cousins. Many endured this great tragedy. But the heart and nerves of every Korean nation spilled like mulberry. When he sees that the criteria of humanity have been violated, everyone's body is shaken.

The main idea of the author's story "Stray bullet"is to show the nihilism of that time (lack of human dignity) and to realistically express the fate of people in the years after the Civil War, the difficulties of life.It is these events that are expressed through the life of the protagonist Cholho[4]. No matter how much he misses his homeland, the 38th parallel line is now drawn through the image of a mad mother who cannot return to those lands, the country is divided into two, to fulfill his mother's dreams he first enlisted in the army and then returned to join the hooligans 
because of unemployment. , the life of the youth of that period is emphasized through the image of Yong-ho, the brother who invaded.Her sister, Myongsuk, goes into a brothel to make a living, and when she gets home late, she shakes her mother's hand and cries in the morning without telling anyone, but no one understands the pain inside her. He spends the money he earns on his daughter-in-law's hospital expenses. The protagonist's wife, who was a very beautiful and unique musician during her student days, could not bear the pain of fate and died in childbirth.Chol-ho's daughter was suffering from dystrophy (excessive weight loss).

In this situation, Chol-ho, who is trying to live honestly, takes the taxi and repeats the words "let's go, let's go" without knowing where to go. In the play, the word "let's go" has two meanings. "let's go, let's go" - these words are the monologue of the work. Chol-ho's worthless childhood, his mentally ill mother, his wife who forgot that he had been a beautiful musician for years, his wife and daughter, his unconscious daughter, his helpless brother who stole, and his prostitute sister.

The repetition of the words of the mother of the family living in the wheel of this destiny "let's go, let's go" adds to the impact of the work. The mother's word "let's go"means a return to the past, to the place where the umbilical cord blood was shed. This "homeland" is a prosperous life before the war, a time of priceless human dignity. The Chol-ho family had no choice but to leave their war-torn homeland. Now the family lives in poverty and longs for the "homeland" of the past.But even though he knew that there was no way back to his "homeland," the desperate mother's words "Let's go, let's go" crushed Chol-ho's heart even more. At the end of the play, however, Chol-ho repeats the words "Let's go, let's go" over again, even though he doesn't know exactly where to take a taxi.

At that time, his brother Yong-ho was in prison because of the invasion, and his pregnant wife had died in childbirth.It was at the moment when these misfortunes were intertwined that Chol-ho had to go somewhere, but he was so stunned that he didn't know where he was.Chol-ho's word "let's go" means to leave these misfortunes behind and go somewhere. In the play, brothers Chol-ho and Yong-ho have very different views on life. Although Yong-ho completed 3 years of university and went into military service, he had not yet taken up any profession.He joins three or four hooligans like himself and spends his day having fun every day.The life of his brother Chol-ho, whose monthly salary was not enough to feed Yong-ho, seemed very poor. Chol-ho, on the other hand, believes that in any case it is necessary to live in a right, honest way without selling one's conscience.But Yong-ho does not want to live like his brother, he can find the strength to sell his conscience, his faith and set aside the rules. Yong-ho, who has dreamed of living life to the fullest since he was a child, enlisted in the army only to fulfill his mother's dreams, but he was deeply saddened by the fact that he lived a life of obedience to the rules and wasted his time does not hold.

In the oral tradition of many peoples of the world, various versions of fairy tales about two brothers: a wicked, a badtempered, a stingy brother, and a poor but well-behaved brother are famous. The classic Korean work "A Tale of Xinbu" is based on the motifs and plot of such a folk tale and does not deviate from the traditions of folklore at all: wicked, vicious, stingy brother, and a poor, open-hearted, gentle, pious, able-bodied brother who does not try to defend himself, who unconditionally, obediently accepts the hardships of life.Just like in fairy tales, a brother always insults and insults his brother, and then the poor brother is kicked out of his parents 'house. $\mathrm{Xinbu}$ is starving and naked on the street with his wife and children.

This story by Lee Bom Son is like a modern fairy tale about brothers: their attitude to life is understood through the situation of the brothers in the story during the "smoking" period:Chol-ho believes that 
no matter how helpless and difficult you are, you should live honestly.Yong-ho, on the other hand, is afraid to live like his brother, to live an unhappy life without achieving the goals he wants in life.Yong-ho believes that it is impossible to live in this world with a clear conscience, and prefers to feed his stomach, even if it is against the law, than to live in poverty with a clear conscience.

As the author writes down the events of the post-Civil War years, he raises the question of how one should actually live. He tries to find an answer to this question through his brother's worldview and lifestyle.Yong-ho is eventually imprisoned in a flood of his dreams and hopes, while Chol-ho tries to live honestly and conscientiously, but his fate ends when he sees his wife's body in the maternity ward.Chol-ho, who was wandering in a taxi not knowing where to escape from the game of fate, did not really understand how to live.He did not know what to do in a closed street, whether a man should live without forgetting humanity in any case, or whether he should live without tapping anything in the struggle for life.

In "Stray bullet", the protagonist is given a life by his brother, who returned from military service, and his sister, who sold her body to help her family, became a prostitute in the eyes of everyone, and forgot that she was a beautiful musician. To Cholho, who is pure in conscience, this life is also worth living. He was satisfied with everything.

In a medieval story, the conflict ends with the victory of good over evil:Nolbu loses his wealth, and Xinbu becomes a wealthy man who has his own house with his hard work and good manners. The rule that everyone must do their duty to others serves as the leitmotif of the story.Adherence to the exact duty leads to the victory of good over evil. In the modern story, however, the conflict between society and man ends in tragedy.
This work is able to fully reflect the tragedy of the nation divided in the years after the Civil War. Chol-ho, a mother who remembers her homeland with the words "Let's go", a woman who died before she could give birth to a child, Yong-ho, who was sentenced to life imprisonment, went to the street of prostitution. The sister who entered could not enjoy life because of the great tragedy that befell the people who did not understand who the nation was divided, who was fighting, and why.

\section{Conclusion}

In medical science, there is a term called analgesia, which means a serious illness.A characteristic symptom of this disease is the loss of the ability to feel pain in his limbs. If this is not done immediately, the person will die. Nowadays, another term has emerged that corresponds to the moral and aesthetic views of western countries, or rather to express their ideas. This is called aurafia [5. 57]. This term is applied to people who are indifferent to all that is happening around them, in a positive sense for them, of course.In our opinion, this is a more serious pain than analgesia. Because such people do not have the feeling of rejoicing in beautiful events, of suffering from disgusting reality, They are literally selfish people devoid of human suffering.It means that they do not have love and affection for their homeland and people. This is clearly seen in the image of Yongho.

Life was like a Stray bullet that had lost its destination. Rather than depicting the difficult life after the Civil War, the work emphasizes that man should not forget humanity in any case.The life of Chol-ho can be interpreted in two different ways. The first was the society's law of living without selling conscience and faith, not going beyond poverty, not getting out of financial trouble, and the second was that the conflict between the South and the North caused the divided body to suffer from not being able to 
unite. Through his portrayal of Chol-ho, who observes the tragic life of his family without removing the "needle" of conscience from his body, the author asks the reader the path one must follow in order to remain pure in life after the Civil War.

\section{References}

[1] Oljaboev U. The demands of the times and the responsibility of the creator. Tashkent: "Uzbekistan". 2012. p.108.

[2] Azimov G . Translation theory. Tashkent: Teacher, 2006.

[3] Izzat Sultan. Literary theory. Tashkent: Teacher, 1986.

[4] 권영민편.한국현대문학대사전.서울대 학교출판부 .-서울, 2004.

[5] Hakimjon Karimov. Literary portraits. Tashkent: New Edition, 2017, -p.57.

[6] Turakhanovna, S. U. (2020). The Issue of Literary Heroism in Korean Literature. Solid State Technology, 63(6), 1779-1785.

[7] Saidazimova U. T. The Elements Organic Culture of Korean People.International Journal of Pharmaceutical Research (IJPR), Pp. 522-525.

[8] Odilov, B. A., \& Karimov, N. R. (2020). ANALYSIS OF TARGETED RESEARCH IN 20-30 YEARS OF THE XX CENTURY. PalArch's Journal of Archaeology of Egypt/Egyptology, 17(6), 8887-8893.

[9] Qosimova Sh.S. Historical Roots of Korean Medicine.International Journal of Pharmaceutical Research (IJPR), Pp. 554-557. 